\title{
Moral Objectivity, Simplicity, and the Identity View of God
}

\author{
GoRdOn PETTIT \\ Philosophy and Religious Studies \\ Western Illinois University \\ Macomb, Illinois
}

Let $\mathrm{O}$ be the proposition that the fundamental principles of morality are objective, universal and invariable, not arbitrary or varying according to the beliefs or values of a particular culture or an individual person.

Let $\mathrm{G}$ be the proposition that God is the ultimate source or grounding of the fundamental principles of morality.

Though $\mathrm{O}$ and $\mathrm{G}$ are not cited specifically, the received view is that fundamental principles of morality cannot be both objective, universal and invariable and also theistically dependent. When presented with $\mathrm{O}$ and $\mathrm{G}$, the common response is that their conjunction is either inconsistent or incoherent. I explore the idea that God is the Good, which, if true, would provide a basis for affirming the conjunction of $\mathrm{O}$ and $\mathrm{G}$. I defend the truth of neither $\mathrm{O}$ nor $\mathrm{G}$, but instead intend to show that their conjunction is consistent and coherent.

Objectivity involves mind independence, but the objectivity of concern here must be qualified. While the fundamental principles of morality may be dependent on the nature of humans, including characteristics of our minds, the important aspect of objectivity is that human minds have no role in creating moral principles. The characteristics of universality, invariability, and independence of human minds (as qualified here) are the defining features of $\mathrm{O} .^{1}$

Both $\mathrm{O}$ and $\mathrm{G}$ refer to "fundamental principles of morality." This is a technical phrase referring to moral principles of obligation or prohibition

\footnotetext{
ABSTRACT: I argue that one can consistently affirm that fundamental moral principles are objective, universal, nonarbitrary, and invariable and yet are dependent on God. I explore and reject appealing to divine simplicity as a basis for affirming this conjunction. Rather, I develop the thesis that God is identical to the Good (the Identity View or IV) and argue that the IV does not fall to the criticisms of simplicity. I then consider a divine will theory (DWT) that claims moral principles are grounded in God's will. The IV conjoined with the DWT show the consistency of the initial conjunctive claim.
}

1. A second qualification of objectivity, related to the "mind" of God, is required, but can only be developed clearly after further consideration of the nature of $\mathrm{G}$, and is addressed in section 4. 
that are similar to the fundamental principles of competition (for particular sports or warfare) or music (including stylistic distinctions and principles particular to performances) and unlike foundational mathematical or logical principles. There will not be a specific universally accepted list of fundamental principles, but instead there are loosely associated families of principles. These kinds of fundamental principles are among the first one should learn in order to understand a discipline or area of inquiry. They are applicable in a wide variety of cases and can be used to derive other more particular principles.

It is broadly accepted that Socrates long ago showed us that affirming both $\mathrm{O}$ and $\mathrm{G}$ (or some similar pair of claims) is inconsistent or at least incoherent. The stronger view is that these two propositions are contraries. The problem in affirming both $\mathrm{O}$ and $\mathrm{G}$ may be presented as a dilemma. If the principles of morality are objective, universal and invariable, then they are not dependent on individuals, cultures, the gods or any individual God, since those things may vary in their values, beliefs, preferences or decrees. So God could not be the grounding of morality. So if $\mathrm{O}$ is true, then $\mathrm{G}$ is false. But if God is the ultimate source of moral principles, then morality is relative, particular and variable according to whatever God prefers or commands; God could change his mind about any moral principle or declare some to apply for certain people but not for others. Even if God were to decree that moral principles shall not vary, the decree could later be rescinded by God, with ensuing changes. (A paradox may be lurking nearby but without a theological basis to the contrary, God could change his own decrees.) So if $\mathrm{G}$ is true, then $\mathrm{O}$ is false. $\mathrm{O}$ and $\mathrm{G}$ cannot both be true, though of course they could both be false. Others may deny that the contrariety is present, yet argue that to affirm both $\mathrm{O}$ and $\mathrm{G}$ is to hold an incoherent position - one that does not overtly violate logical principles, but only because $G$ is insufficiently explicit. The suspicion is that once one begins to explicate $\mathrm{G}$ with a substantive theoretical framework that could explain what makes $G$ true, the difficulties will become apparent. "Coherency dilemma" is a broad label to cover both objections. The coherency dilemma is the claim that affirming both $\mathrm{O}$ and $\mathrm{G}$ is either inconsistent or incoherent.

There are four possible responses to the coherency dilemma. One could simply respond that both $\mathrm{O}$ and $\mathrm{G}$ are false, so the apparent problem is of little concern. Three other responses are more interesting. One could affirm $\mathrm{O}$ while denying $\mathrm{G}$. This route is clearly viable for nontheists, but many theists also prefer this response. Theists who take this route may also deny that God's moral authority is undermined when "identifying" or "announcing" moral principles rather than being their source. For example, John Arthur suggests that accepting this apparent moral limitation on God may be compared to God being unable to do what is logically impossible; he concludes 
that it is an acceptable limitation for a theist, or no limitation at all. ${ }^{2}$ Another option open to theists is to affirm $\mathrm{G}$ while denying $\mathrm{O}$, thus endorsing a theistic relativism in the spirit of Kierkegaard. According to this view, God is not constrained by invariable moral principles and his will or commands may fluctuate accordingly. Though murder is wrong, if God commanded murder, then it would be right. A fourth option is to affirm that $\mathrm{O}$ and $\mathrm{G}$ are both true and their conjunction can be affirmed with consistency.

I defend the coherency of the fourth option. The primary task will be to make $\mathrm{G}$ more explicit in order to avoid charges of covert incoherency. Through what many may consider a foolhardy plan when attempting to avoid the charge of incoherency, I shall borrow from the doctrine of divine simplicity in order to accomplish the task. I consider the possibility that God is a perfect being identical with the Good - the paradigm and standard of what is good - and this identity is fundamental for moral evaluations. This is the central guiding idea of what may be called the Identity View or IV. The IV is not to be confused with the "Identity Thesis" (IT) of Brain Leftow, which is much broader in its identity claims. ${ }^{3}$ The IV provides resources for an adequate response to the coherency dilemma, and I shall defend its coherency. I shall not, however, provide arguments for its truth, which is well beyond the scope of this paper. Instead, the goal is to defend the coherency of affirming both $\mathrm{O}$ and G. I provide a descriptive, consistent model for IV, showing that the IV is possibly true.

Defending the coherence of affirming both $\mathrm{O}$ and $\mathrm{G}$ will proceed in four stages corresponding to four sections. The first section examines the potential of appealing to the doctrine of divine simplicity in responding to the coherency dilemma, as some have attempted. The second section considers objections that have been directed toward the doctrine of simplicity, with an eye toward how they may be relevant to the IV. The third section compares and contrasts the doctrine of simplicity with the IV, and defends the IV from the difficulties identified for simplicity and considers further complications that may be raised for the IV and corresponding responses. The fourth section briefly outlines a moral theory developed in conjunction with the IV, that implies $\mathrm{G}$ and is consistent with $\mathrm{O}$. Since the moral theory is internally consistent, consistent with $\mathrm{O}$, and implies $\mathrm{G}$, it follows that $\mathrm{O}$ and $\mathrm{G}$ are not contraries. Furthermore, the development of the IV will assuage concerns regarding any hidden incoherence, showing the coherency dilemma to be unfounded. The paper concludes with some brief reflection on the motivation of the project.

2. John Arthur, Morality and Moral Controversies, 6th ed. (Upper Saddle River, NJ: Prentice-Hall, 2002), 66.

3. Brain Leftow, "Is God an Abstract Object?" Noûs 24 (1990): 581-98. Also, just to avoid confusion, one should pronounce "IV" like the word "ivy," not "four." 


\section{The Potential Role of Using Divine Simplicity}

Several medieval thinkers took on both horns of the coherency dilemma by appealing to divine simplicity, roughly the idea that God is without complexity in his essential intrinsic nature and is identical with this nature. Though affirmed by such eminent thinkers as Augustine, Maimonides, Avicenna, Aquinas, and others, simplicity has also been labeled "the strangest and hardest to understand" doctrine among the Medieval theologians ${ }^{4}$ and "one of the most difficult and perplexing tenets of classical theism." ${ }_{5}$ These are not encouraging endorsements of simplicity, but with a history of such esteemed supporters who also have inspired many contemporary advocates, the doctrine's value is worth investigating. Being strange and difficult to understand need not mean that it is incoherent or not possibly true. According to simplicity, God is the source of moral principles and he is not inferior to an external source, while it is also the case that the moral law is eternal and invariable, since its source is the eternal unchanging divine intellect, which in turn is identical with perfect goodness, that is, God. That is the extremely abridged description of simplicity and its relation to morality.

The identity view that I develop makes no claims about complexity, so it would be inappropriate to label the view a version of simplicity. Though it is not a version of simplicity, there is a debt owed to proponents of divine simplicity. I borrow from what I understand to be an important feature of the doctrine of simplicity, an idea rooted in Plato but developed in a unique fashion in Aristotle's metaphysics.

In contrast, a recent medievalist, Norman Kretzmann, argues that the coherency dilemma can be resolved with an adequate understanding of the simplicity of God. ${ }^{6}$ Kretzmann emphasizes that God is identical to each of his attributes, including his goodness or perfect goodness. If God is identical with perfect goodness, then there are consequences when we contemplate issues about morality. Kretzmann affirms two claims, TO', which is a claim about objectivity and TS', which claims that the morality of actions depends on God's approval.

$\left(\mathrm{TO}^{\prime}\right)$ "'God conceived of as a moral judge identical with perfect goodness itself approves of right actions just because they are right and disapproves of wrong actions just because they are wrong." 7

4. Eleonore Stump, "Simplicity," in Companion to Philosophy of Religion, ed. Philip Quinn and Charles Taliaferro (Cambridge, MA: Blackwell, 1997), 250.

5. Thomas Morris, "On God and Mann: A View of Divine Simplicity," in Anselmian Explorations (Notre Dame, IN: University of Notre Dame Press, 1987), 98.

6. Norman Kretzmann, "Abraham, Isaac, and Euthyphro: God and the Basis of Morality," in Philosophy of Religion: The Big Questions, ed. Eleonore Stump and Michael J. Murray (Malden, MA: Blackwell, 1999), 417-27.

7. Kretzmann, "Abraham, Isaac, and Euthyphro," 426. 
TO' preserves objectivity and avoids the charge of arbitrariness or relativism. But he also affirms

(TS') "Right actions are right just because God conceived of as a moral judge identical with perfect goodness itself approves of them and wrong actions are wrong just because God conceived of as a moral judge identical with perfect goodness itself disapproves of them."

TS' (with minor and plausible assumptions) implies $\mathrm{G}$ and preserves God's independence and moral supremacy. His two claims describe the relation between morality and God in a manner that shows he affirms the consistency of $\mathrm{O}$ and $\mathrm{G}$. He further argues that his two statements are merely two ways of saying the same thing. There is no true dilemma, and a theist does not have to choose between $\mathrm{O}$ and $\mathrm{G}$, but can consistently and coherently affirm both. The identity view that I develop is motivated by a perfect being theology similar to Kretzmann's and the implications for moral standards are similar, but significant differences will become evident.

\section{Problems with Simplicity}

Kretzmann's work is exemplary of the strategy of responding to the apparent inconsistency of $\mathrm{O}$ and $\mathrm{G}$ by appealing to divine simplicity. Making use of the doctrine of simplicity shows a lot of promise and even some proponents of the coherency dilemma think that utilizing divine simplicity may provide a way to avoid the dilemma. For example, discussing a version of the coherency dilemma, Wes Morriston agrees that "Those who accept the doctrine of divine simplicity can pass unscathed between the horns of this dilemma. If God is God's nature, the problem disappears. Since God's nature is not something over and above God, there can be no question of its providing a standard of moral goodness apart from God." Y Yet Morriston clearly does not endorse this approach. ${ }^{10} \mathrm{He}$ states that he is among those who cannot see how God could be his nature or how his nature could be simple, and so the apparent resolution offered by an appeal to divine simplicity has no value. Morriston follows Alvin Plantinga and others in their two-pronged objection. First, they claim that simplicity is incoherent because God cannot be an attribute or property and second they argue that God's various properties cannot be identical, even if only his intrinsic essential properties are considered. Morriston argues that utilizing the insights of simplicity, though promising

8. Ibid.

9. Wes Morriston, "Must There Be a Standard of Moral Goodness Apart from God?" Philosophia Christi 3 (2001): 129-30.

10. Ibid., 130; see also Wes Morriston, "What Is So Great about Moral Freedom?" The Philosophical Quarterly 50 (2000): 353-5. 
in one sense, ends up having little value because simplicity is itself an incoherent thesis.

In order to evaluate these objections, let us clearly identify where the problems lie. First the objectors deny that God can be identical with his attributes. If it is true that God is perfect goodness, then simplicity implies that this is to be understood as an identity claim. If God is identical with perfect goodness and perfect goodness is an attribute, then God is an attribute. But most theists (and even nontheists) would not be satisfied with the implication that God is an attribute. ${ }^{11}$ The second apparent problem with simplicity is that it implies that all of God's attributes are identical. But even if the attributes are qualified as perfect knowledge or perfect power, for example, there are apparent inconsistencies in identifying omniscience as omnipotence. These and similar problems of consistency give reason to claim that simplicity fails to account for God's nature.

A third, more indirect objection against simplicity focuses on the claim that God is immutable and thus is unchanging and lacks all accidental attributes. Simplicity implies immutability, for there is no potential for change if an entity is simple. The medieval proponents of simplicity did not regard this as a significant challenge that required a response, but rather an advantage of simplicity. Yet problems may arise when considering the relation between God and creation. His knowledge would seem to be limited, since it would not fluctuate according to the day to day (and moment to moment) changes that occur in the world. Furthermore, it seems God could neither answer prayer nor respond to free choices - actions believed to be important by most religious practitioners. While the former problem may be covered by an appeal to God's timelessness (which in turn introduces a new set of challenges), it is more difficult to handle the latter concern with a similar response. The problem is not simply a tension between freedom and God's foreknowledge, which befalls anyone affirming the existence of both of these, but rather, there is a special problem for simplicity. For many religious practitioners, prayer involves interacting with God by synchronous communication and is an important part of their religious practices and is also interwoven with their religious beliefs. Such interaction with the deity does not seem possible if the deity is entirely immutable. Of course, one might respond by claiming that religious practitioners are widely mistaken in their beliefs about prayer, but for those who claim that a more robust interaction between God and creation is possible, the problem arises. Certainly, some of the medieval writers and contemporary proponents address this challenge, yet the issue of immutability seems worthy of serious consideration due to its significance for many

11. E.g., Morriston and also Alvin Plantinga, Does God Have a Nature? (Milwaukee: Marquette University Press, 1980), 37-61. Notable exceptions include Brian Leftow, "Is God an Abstract Object?" and William Mann, "Simplicity and Immutability in God," International Philosophical Quarterly 23 (1983): 267-76. 
believers: in brief, if God is immutable as simplicity implies, his knowledge of and interactions with the created realm may be severely restricted.

\section{How the Identity View Escapes the Challenges to Simplicity}

My assessment is that the difficulties described above are insurmountable for the traditional doctrine of simplicity and give reason to avoid the central claims of simplicity. But there are aspects of simplicity that are appealing and may provide resources for addressing the coherency dilemma. As noted by Kretzmann, simplicity is motivated by a theological commitment to God's independence of and power over all other entities - God's aseity and sovereignty. A motivation for affirming $\mathrm{G}$ is an attempt to maintain the aseity of God. Or better, as one considers the aseity of God, there is motivation to affirm something like G. Proponents of simplicity are committed to G primarily due to the claim that God is identical with his goodness or perfect goodness.

While this identity claim leads directly to the first objection against simplicity, the IV does not fall prey to that objection since it explicitly denies that God is identical with an attribute. The IV differs from simplicity while affirming another identity claim. According to the IV, God is identical with the Good. The IV maintains that there is one God, and that God is the Good - both the paradigm and the standard of everything that has an attribute of being good. But the Good is not itself an attribute.

The identity is a Platonistic claim, but does not import all of Plato's metaphysics. The identity claim of the IV is similar to one that forms the basis of some recent work by Robert Adams. ${ }^{12}$ Some problems related to claiming that God is the Good are adeptly described in Timothy Chappell's review of Adams's book. ${ }^{13}$ Chappell's chief criticism of Adams's foundational identity claim is the seemingly veiled meaning of the claim itself. Chappell states that he does not know what Adams means when he says that God is the transcendent Good; a similar concern may be raised against the IV. Part of the problem lies with Plato's work. Chappell offers three ways of understanding Plato by describing three versions of Platonic forms: universals, paradigms, and standards. Each of the three have unique existence conditions, forcing one who utilizes Platonic forms to make a choice about which understanding of the forms he has in mind, a choice that Chappell claims Adams fails to make. Universals are abstract objects that exist as properties do, apart from their instantiations. Paradigms are concrete objects that are the perfect

12. Robert Merrihew Adams, Finite and Infinite Goods: A Framework for Ethics (New York: Oxford University Press, 1999).

13. Timothy Chappell, review of Finite and Infinite Goods: A Framework for Ethics, by Robert Merrihew Adams, Faith and Philosophy 19 (2002): 373-8. 
instances of properties - objects that are absolutely perfect in respect to their form. Standards are criteria that allow judgments to be made and only exist when there is a determinate method of measuring based on the standard. ${ }^{14}$ Clearly, neither Adams nor the IV refer to universals when making the primary identity claim. It is the meaning and consistency of the second two options that are relevant to the IV. The primary concern is explicating the identity claim that God is the Good.

In claiming that God is identical with the Good, it is both fruitful and dangerous to refer to Plato's form of the good. It is helpful since we are familiar with some of the basic traits of the Platonic form of the good. Due to a familiarity with Plato, we may be more apt to grasp what the IV is claiming. However, it is also dangerous to evoke Plato's forms, since we are also familiar both with criticisms of Platonic forms in general and some prima facie problems with identifying God as the form of the good. These are similar to the difficulties that led to Chappell's criticism of Adams.

Keeping in mind the danger, let us consider how to understand the claim that God is identical to the Good, comparing and contrasting this idea with Plato's discussion of the forms, especially what he has to say about the form of the good in the Republic. Plato's form of the good is no ordinary Platonic form and has special status in the universe. It is set apart from other forms and some of the differences are helpful for understanding the Good to which the IV refers. As a paradigm, nothing could be more good than the good itself. With apologies to Anselm, God is the being than which none better can exist. There is no lack of goodness in God, just as there is no lack of goodness in the Platonic form of the good.

Some linguistic concerns may arise for the IV as they did for Platonic forms when understood as paradigms. Self-predication of forms proved problematic for Plato. But for the form of the good, self predication is appropriate; the form of the good is good. Likewise, the IV maintains that the Good is good. The IV need not include commitments to the existence of other forms, and even if other forms exist, the IV need not be committed to self predication for them. So the IV avoids some of the most basic difficulties associated with self predication that Aristotle and others have described (for example, negative and privative forms are problematic in this regard). At the least, the more challenging criticisms of self predication do not arise for the form of the good, as it is not a negative or privative form.

Yet, there is another objection about self-predication that is relevant for our concerns. Some argue that the meaning of "good" when predicated of the Good would be vacuous. If the meaning of "good" derives from the Good, then the claim that the Good is good is wholly uninformative and at best amounts to little more than saying that the Good has the property of self-resemblance. Thus, saying that God is good lacks any value and is not 
really an informative or evaluative statement at all. So if the IV is correct and God is the Good, then one cannot communicate anything of value when claiming that God is good. This seems to undermine an important theological doctrine.

In response, we should clarify that when the statement "Good is good," is made, there is a three-fold ambiguity. One meaning is the central claim of the IV, that God is the Good. That is not our concern here. Another meaning is when the predicate "good" is used as a nonmoral evaluation. In this case, the adjective is used univocally, or at least as univocally as in uses of the term across varying kinds. No more change in the meaning of term "good" is suggested when applied to God than the differences when predicated of an apple, a movie or the weather. There is a core univocal meaning that applies across kinds and to God as well. ${ }^{15}$ In this case, the term "good" retains the same meaning, whether one believes that goodness owes a metaphysical debt to the Good or not. As such, there is no vacuity in the claim.

The meaning that is most relevant involves a moral evaluation. Assume the identity claim that God is the Good. The challenge is how can it be meaningful to predicate moral goodness of God by saying that the Good is good. Suppose that Marie is fairly adept at identifying what is good, but errs when referring to God by saying that God is not good. She suffered an unfortunate loss, and though she believes that God exists and may be good in a nonmoral sense, she has concluded that God is not morally good. Such a case would be analogous to someone (Jason) who does not know the scientific standard for one meter but who can still accurately measure the length of things in meters - except he errs when assessing the distance that light travels in $1 / 299,792,458$ of a second (the current standard) as much less than a meter. Suppose further that through some reflection or conversion and subsequent change of thought, Marie changes her assessment of God. She may eventually state to a friend that she was mistaken and God is (morally) good after all. This claim is substantive and (supposing it is true) informative, even though what it is to be good ultimately derives from the Good itself. It is appropriate, substantive and potentially informative for Marie to predicate "good" of the Good. Her understanding of the basic meaning of the term does not change. Instead, her understanding of God has changed. And if Jason comes to learn that the distance light travels in $1 / 299,792,458$ of a second is the current standard for a meter, he also will realize his previous error. But when he says that the distance that light travels in $1 / 299,792,458$ of a second is one meter, he is not making a vacuous claim.

The analogy is imperfect of course, as the length of a meter is (arguably) not necessarily dependent on light traveling a certain distance in a particular amount of time, while the IV claims that what is good is necessarily depen-

15. This does not rule out all use of analogical language in reference to God. E.g., when we speak of his creativity or his mind, these may be used analogically. 
dent on the Good. But the point remains; one can know the meaning of and appropriately use a term without understanding the metaphysics or physics behind it. But suppose further that Marie increases in her understanding of God and learns that God is identical to the Good. She now has a richer understanding of what it means to say that something is good. Does she retract her previous claim that God is good? Does she conclude that it was meaningless or vacuous to make such a claim? I argue for the negative response in both cases. On the contrary, her understanding of the claim is enriched and when she ponders the goodness of God, she has a more fulfilling understanding of him and his creation. She stands by her claims all the more and affirms their meaningfulness. She believes something new that she had not believed before and the new belief holds great significance for her. The substantive nature of her claim should become even more apparent as we continue to examine the similarities between the Good and Plato's form of the good.

Plato's form of the good is much more than a mere paradigm and is likened to the sun. It has ontological priority such that the other forms and ultimately everything else in the universe owes its existence to the form of the good. ${ }^{16}$ If the Platonic form of the good did not exist, then nothing good would exist because nothing would exist at all. Similarly the IV claims that God has ontological primacy in the universe and is the ultimate source of everything that exists. Of importance to the proponents of the IV, justice, virtue, and other aspects of the moral realm are fully dependent on the form of the good. Plato's form of the good is a paradigm without which all moral evaluators would fail to exist. The IV also claims that the Good is the standard by which we evaluate the good of other things, including but not limited to moral worth, moral virtues, and the morality of actions. For Plato, whatever is good is good because of participation in the good. Similarly the IV maintains that whatever is good or right is so because of some relation to the Good.

The Good as a paradigm has been described; a remaining task is to explicate how the Good is a standard. The Good is clearly not a standard in Chappell's sense, since it is not itself a method of measurement and it does not imply a determinate method of measurement. Rather, the Good is a model by which other entities may be compared, though never clearly and precisely due to our fallibility in perceiving the standard. This may be a mere expansion of the idea of a paradigm; in any case, it seems that not all standards need to be publicly identifiable and serve as a practical utensil for measurement, as Chappell claims. In many cases (for example, art, music, philosophical writing) where experts agree that standards exist, disagreements abound over whether certain works are up to the standards, and in some cases what the standards are. In the same way, the Good could be a 
standard even though measuring by that standard inevitably includes practical and epistemological obstacles.

The IV's claims about the Good are similar to a manner of speaking that is often used as a slightly humorous, literally false, yet still informative illustration. Suppose someone says, "When you look up 'basketball player' in the dictionary, you will find a picture of Michael Jordan." The saying is motivated by the assumption that Jordan has (had) all of the good qualities that an excellent basketball player should have, thus deserving to be the ultimate standard by which all other basketball players are measured. One after another is evaluated on whether or not he could be "the next Michael Jordan." The Good is a standard for morality in a way similar to how Jordan is a standard for basketball players. Clearly, Jordan is not the perfect exemplar of a basketball player in the way that God is the perfect exemplar of what it is to be good, but to borrow this type of illustration, the IV claims that if you want an ostensive definition of "the Good," you need look no further than God. Thus, the IV claims that God is the Good - the paradigm and standard of goodness.

Furthermore, this claim is no more arbitrary than any other view that identifies something as constitutive of goodness. As William Alston has argued, whether the supreme standard of moral goodness is a general principle or an individual standard or paradigm, there must be an end of the line. ${ }^{17}$ Claims about brute facts cannot be explicated further; it is not arbitrary to stop where there is no possibility of advancing any further.

Though the IV is similar to Alston's views, primarily in the claim that God is the supreme standard of goodness, ${ }^{18}$ Alston does not develop the metaphysics of his view or the relation of his claims to simplicity. Also, I disagree with Alston in his claim that talk of God's moral goodness is at best analogical to talk of human goodness. Comparable to the comments above in the context of nonmoral goodness, it seems that there is a core univocal meaning of moral goodness that applies to God and to humans. Though God's patience is much different than our patience, there is a core meaning to patience such that it is entirely appropriate to say that we are patient in the same way that God is patient. The degree, depth, and limits of patience is different when speaking of God than it is when we speak of humans, but what characteristic or trait we are speaking about is the same. ${ }^{19}$

In explicating the claim that God is the Good, we have addressed the first objection against simplicity as a resource for affirming both O and G. The IV rejects the claim that God is identical with his attributes since the Good

17. William Alston, "What Euthyphro Should Have Said," in Philosophy of Religion: A Reader and Guide, ed. William Lane Craig (New Brunswick, NJ: Rutgers University Press, 2002), 293.

18. Ibid., 291.

19. The claims about univocal language as described here are similar to the position defended by Scotus in Book 1, Distinction 3 of The Commentary on the Sentences. 
is not an attribute, but is instead a being who is the paradigm and standard of what it is to have the attribute of being good. The second objection against simplicity is that various attributes, especially power and goodness, cannot possibly be the same even when perfected. The IV escapes this objection, since it does not make the claims about power or knowledge that the doctrine of simplicity includes. Our use of the Platonic form of the good has been helpful in gaining insight into the nature of the Good in a way that does not lead to the first two and most significant difficulties that simplicity faces.

But here the use of Platonic ideas (pun intended) reaches the end of safe terrain and enters the dangerous area warned of above. There are limitations to using Plato's forms in order to understand God as the Good, for the IV denies some of Plato's claims about forms. One obvious difference already mentioned is that Platonic forms are sometimes best understood as universals, but that can be ruled out as a model for considering God as the Good. Also in contrast to Plato, the IV claims that the Good is a living, thinking and personal being, whereas Plato's forms are inert. We must make a departure from Plato's forms in order to explicate further the claim that God is the Good.

While a departure from Plato is necessary, it is appropriate to progress on to the writings of Aristotle about God. Like our use of Plato, we can only borrow some of his ideas and not simply identify God as Aristotle's God. But we are familiar with Aquinas's use of the metaphysics of Aristotle; both refer to God as the prime mover, an eternal living being, and that which is the greatest good..$^{20}$ It is no coincidence that Aquinas produced fruit by using Aristotelian seeds, and likewise there are significant points of agreement between Aristotle and the IV. Like Aristotle, the IV claims that the Good is God and is a single, eternal, living being capable of thought. God is the source of all being, the eternal living being that is rational (the logos) and "that for the sake of which" anything else is called good. All of these metaphysically rich ideas are included in the claim that God is the Good. The most significant concept lacking in Plato that we gain from Aristotle is the Good having the attributes of being a living God who is capable of rational thought.

Being a thinking being leads us to consider the third objection against simplicity that confronts many traditional believers. Aristotle's metaphysics can help address this concern, if only in a limited way. The third objection is that if God is immutable as simplicity implies, his knowledge of and interactions with the created realm would seem to be severely restricted.

This objection may be addressed by considering to what degree the IV is committed to immutability. The IV does not affirm the immutability attributed to Plato's inert form of the Good. But it also does not affirm the weaker

20. For Aristotle, see Metaphysics book 12, sections 5-8, especially 1072a19-26, 1072b1431, and 1074a30-38. For Aquinas, see Summa Contra Gentiles, Book 1, chap. 13. 
type of immutability of the active God of Aristotle. ${ }^{21}$ Here, the IV departs from some lines of tradition, and allows for the possibility that God changes by interacting with particulars, while maintaining incorruptibility in moral perfection. The IV maintains that God, as identical with the Good is incorruptible in moral character (with "character" understood analogically). There never has been nor will there ever be a change in the moral character of God. Though incorruptible in character, the IV does not claim that God is entirely immutable. For example, God's knowledge changes as the created realm changes, in contrast to Aristotle's claims about God. Aristotle argued that God's activity had to be of the highest kind - that of thought, and that the content of God's thought had to be of the highest subject, which could only be its own activity. Like Aristotle, the God of the IV has the greatest form of thought, but unlike Aristotle, the IV considers the greatest form of thought to be omniscience, including knowledge of particulars in a changing world. On this topic, the IV's view of God is more like another ancient thinker, Xenophanes, who claims that God is active and a thinking being, but denies the limitation on the content of thought. Xenophanes' God sees, hears, and moves things by his thoughts; the IV concurs.

The IV takes into account those traditional religious practitioners who are motivated to claim that God interacts synchronously with the world, partially due to scriptural texts. Some Hebraic passages, such as those describing God's response to Hezekiah's prayer and his change of plans for the destruction of Nineveh, give at least prima facie reasons to think that God is not immutable in all of his properties, since he seems to be able to respond to a changing world. These passages are also understood in light of theological claims and other scriptural passages that affirm the incorruptible character of God, both consistent with the IV..$^{22}$ Unlike Aristotle's God, the IV considers God as a being who can interact with creation and has the apparent ability to change plans in response to particular actions. Just as with a person of integrity, moral character can remain constant, while particular intentions may change in response to others. The Good is unchanging in standards of goodness, but is an active, living being.

Skeptics may question how the Good - the ultimate standard for goodness, including moral goodness - can be the kind of being that God is. But why not flip the question? Why could God not be the Good? The meaning is the same of course, but the difference is that in the former question, one naturally assumes a strictly limited and inert entity such as a Platonic form, which precludes that entity from being God. But the latter question is more to the point of what the IV claims. If God is the Good, then the Good has capacities not typically associated with it such as knowing, creating, and

21. That Aristotle's God is immutable is stated most clearly in the Metaphysics at 1073a.

22. E.g., Mal. 3:6 ("I am the Lord, I change not"), and others specific to Christianity: James 1:17 (there is "... no variableness ..." [in God]) and Heb. 13:8 ("Jesus Christ [is] the same yesterday, today and forever"). 
willing. The Good retains the essential assumed properties such as being the paradigm Good and the unchanging standard of goodness for all things. The Good changes, but only in ways that are not relevant to its being a paradigm and a standard. It is similar to having a particular standard of measurement, such as a yard stick made of chromium. Though very improbable, this standard could change in its position, width (by being flattened), color (by being painted), mass (by having a hole drilled in it), and so on, yet still maintain a standard of length. Likewise God could change in knowledge of and interactions with the world. All the while, the Good does change of course, but not qua Good; that is, the nature of the Good remains constant, and any evaluative judgments based on the Good need not change.

The IV can be defended against the three most challenging problems that simplicity faces. But the question of how the God of the IV is related to moral principles remains. Whatever form moral principles take, they will be dependent on the Good and it is clear that $\mathrm{G}$ will be implied by any moral theory that affirms the IV. The remaining task is to flesh out the IV so that the relationship between it and moral principles are more clear.

\section{The Identity View and Moral Theories}

We have not yet shown the consistency of $\mathrm{O}$ and $\mathrm{G}$ by considering the IV, since more details are needed regarding fundamental moral principles. But a theistically-based moral theory, developed within the context of the IV, and emphasizing the relation between the moral theory and both $\mathrm{O}$ and $\mathrm{G}$, can fulfill the task at hand.

Generalizing very broadly and not exhaustively, the three main approaches to moral theories - consequentialist, deontological, and aretaic theories - could be developed as theistically based ethics. I think there is more hope for the deontological approach than the others. But if one wanted to avoid a deontological approach, there are some potential routes. A consequentialist theory may make promoting the good the fundamental moral goal, with the good being defined according to the Good. This is one of the views that Euthyphro attempted to defend without success. ${ }^{23}$ Though Socrates convinced Euthyphro that the idea could not work, there may be hope for it yet, even though it seems to be the least plausible approach. How might it work? To expand on Euthyphro's suggestion, someone partial to a consequentialist view could claim that what is morally good is that which is of benefit to God. What benefits God is that which promotes the welfare of his creation. Some way of evaluating priorities would be needed, for what promotes the welfare of some will be deleterious to the welfare of another, and there are numerous other complexities here. A mere suggestion is that

23. Plato Euthyphro 13a-e. 
the ordering of values may be determined by what most closely resembles God. Thus for example, a rational and creative being would have more value than an inanimate object. Aquinas is more readily and properly understood as providing a divine command ethic or an aretaic account, but even some of his aretaic ideas could provide insight for how this consequentialist route might be developed. He states that "[n]othing, then, will be called good except in so far as it has a certain likeness of the divine goodness. ${ }^{24}$ The fundamental moral principles, centered around promoting the good, would be dependent in turn on promoting the well-being of what has a likeness to the Good. But these mere suggestions of the basic ideas leave significant difficulties and gaps in details.

More plausible would be an aretaic approach. A virtue theorist may emphasize divine motives as a model for human motivations, with moral evaluations based on the nearness that human motives imitate divine motives. ${ }^{25} \mathrm{As}$ a person develops a character that is motivated in ways similar to the ultimate and perfect good, she is maturing morally. God - the Good - could be the basis for making moral evaluations within an aretaic context. If either of these two general methods of developing a moral theory can be consistently developed, they are clearly theistically based and would imply G. Whether the larger project of showing the coherency of affirming both $\mathrm{O}$ and $\mathrm{G}$ could be developed adequately with either consequentialist or aretaic theories is unclear.

It seems that the most plausible fit for a theistic approach is a deontological version of morality such as a divine command theory. The rough idea of a divine command morality is that an action is morally obligatory because that action is commanded by God, and an action is impermissible because that action is prohibited by God. An influential example of a divine command theory has been developed, modified and defended by Robert Adams over the course of many years. ${ }^{26}$ Many other moral theories similar to his have been appropriately labeled as divine command theories. Kretzmann proposes another genus in the family of a divine command morality, though his writing focuses on approval rather than commands. Another theistically based deontological version emphasizes God's will rather than his commands. Any of these deontological approaches would imply the truth of G. What is less clear is whether they can be consistent with $\mathrm{O}$.

For various reasons, I believe a moral theory emphasizing the divine will has advantages over the others. Some of these reasons are developed by

24. Thomas Aquinas Summa Contra Gentiles Book 1, chap. 40.

25. See Linda Zagzebski, "The Virtues of God and the Foundations of Ethics," Faith and Philosophy 15 (1998): 538-53.

26. Recently in Finite and Infinite Goods and also in "A Modified Divine Command Theory of Ethical Wrongness," in Religion and Morality: A Collection of Essays, ed. G. Outka and J. P. Reeder, Jr. (New York: Doubleday, 1973), 318-34, and "Divine Command Metaethics Modified Again," Journal of Religious Ethics 7 (1979): 71-9. 
Mark Murphy and Philip Quinn. ${ }^{27}$ One significant reason to favor God's will over commands as more foundational is the idea that commands seem to be founded upon what one wills. The central claim of divine will theory (DWT) is that an action is morally obligatory because God wills that action, and is impermissible because God wills that the action not be done. Some nuances are also needed to allow for supererogatory acts, but these are possible if one rejects simplicity as I have. Some have described God's will and desires as "layered" such that God has an antecedent will for what ideally should happen, and a consequent will that takes into consideration free actions, for example. Philip Quinn suggests that God may desire but not antecedently will that a person perform a certain action. ${ }^{28}$ Such an action is obviously not immoral but also it is not obligatory; rather it is supererogatory. According to the DWT, the fundamental principles of morality are dependent upon God's antecedent will - they exist because they are willed by God. Since God's will determines the fundamental moral principles, then God is the ultimate source or grounding of the fundamental principles of morality, i.e. DWT implies G. The next task is to defend the consistency of the IV and a DWT with O.

$\mathrm{O}$ is the idea that the fundamental principles of morality are objective (in the qualified sense as described above), universal, and invariable. This means that the fundamental moral principles apply in all cultures, for all humans, without fluctuation. They are constant, not varying according to differences in beliefs or expressed values of a particular culture or an individual person, though the application of the objective principles may vary greatly according to the context. Even if there are great differences in cultural or individual beliefs and expressed values across various times and locales, that does not mean that fundamental moral principles vary according to those differences. Though I do not defend the truth of $\mathrm{O}$, there is no reason to think that $\mathrm{O}$ itself is inconsistent or a source of incoherency and I shall continue to assume with no further defense that $\mathrm{O}$ is internally consistent, possibly true, and thus not by itself a reason for claiming that affirming the conjunction of $\mathrm{G}$ and $\mathrm{O}$ is incoherent.

We are now in a position to clarify the claim of objectivity a bit more. First, a concession: insofar as the mind of God is involved in his willing, there is a sense of mind dependence for fundamental moral principles. One way to soften this concession would be to consider the phrases "mind of God" and "will of God" to be using "mind" and "will" in an analogical sense. Unlike in other cases of univocal terms related to God presented here, one could argue that there is something utterly unique about God's mind and will.

27. See Mark Murphy, "Divine Command, Divine Will, and Moral Obligation," Faith and Philosophy 15 (1998): 3-27; Philip L. Quinn, "Divine Command Theory," in The Blackwell Guide to Ethical Theory, ed. Hugh Lafollette (Oxford: Blackwell, 1999) and "Obligation, Divine Commands and Abraham's Dilemma," Philosophy and Phenomenological Research 64 (2002): 459-66.

28. See Quinn, "Obligation, Divine Commands and Abraham's Dilemma." 
As we talk about these things, there is some anthropomorphizing underlying our language. For example, we have a psychology such that it makes sense to speak of the mind of a human as distinct from the will of a human, but it may not make sense to do so when speaking of God. Whether or not one should say that there is a mind dependence here, depends on one's understanding of the terms "mind" and "will" when speaking of God, and the degree to which these should be understood as analogical. In any case, the IV and DWT together imply that no contingent minds play a role in creating or providing a basis for the fundamental moral principles (given the qualification provided immediately following the initial description of $\mathrm{O}$ and $\mathrm{G}$ ). It is God's will that provides the obligatory aspect that fundamental moral principles have, but these principles are invariable, universal and nonarbitrary.

If God is identical with the Good and the will of the Good is the source of moral standards, then God is the source of moral standards, and he is ultimately what determines whether an action is right or wrong. The fundamental principles of morality are a subset of the will of the Good. While the IV allows for the possibility that the Good can change his will, it is not possible that what is willed is not good. God's consequent will may be variable in ways that the antecedent will is not. In terms of moral actions, the antecedent will of God does not change as it is founded upon the Good. For example, a person may be in a situation that the Good did not will (having to lie in order to save an innocent life), but God's antecedent will that one should not lie remains. The divine will is ultimately dependent on the nature of God, or who God is. The foundational principles of morality remain unchanged, being grounded in the Good, which is immutable in goodness.

If what is obligatory is so because it is willed by the Good, then what is obligatory is objective and invariable since it is ultimately grounded in the immutable Good. The fundamental moral principles are objective, universal, nonarbitrary and do not waver. They may even be necessary, assuming that God is a necessary being. The necessity is a conditional necessity though, for the existence of humans is contingent. Fundamental moral principles may be conditioned on the nature of humans, such that given the Good and the nature of humans, there could not be any variance of fundamental principles. In any case, the DWT in conjunction with the IV is consistent with $\mathrm{O}$. So the IV and DWT imply G and are consistent with O. Thus, as long as DWT and the IV are both internally consistent, $\mathrm{O}$ and $\mathrm{G}$ are not contraries. In response to the coherency dilemma, the one who asserts the IV along with DWT can affirm both $\mathrm{O}$ and $\mathrm{G}$ with consistency. One need not choose one over the other. Furthermore, the IV has been more extensively developed to avoid the charge of concealed incoherency and the various objections of the coherency dilemma are met. 


\section{Motivation and Implications}

A final concern is the motivation for affirming G. Why think that moral norms are dependent on God when other norms, such as epistemic ones are not? If one is motivated to affirm $\mathrm{G}$, why not affirm that all normative principles are dependent on God? Presumably many would find this dependency odd at the least. But for those who may affirm both $\mathrm{O}$ and $\mathrm{G}$, it does not seem a significant problem to accept the more general position hinted at throughout this paper: all normative principles are in some way dependent on God. Working out the details here is well outside the realm of this project, but others have provided more than mere suggestions of how this idea could be developed. For example, Alvin Plantinga's proper function view of epistemology is ultimately one way of fleshing out the idea that epistemic norms are dependent on God, and we have at least one contemporary version of how this implication might be developed. ${ }^{29}$ Other norms such as Aristotelian or biological norms may also depend on God in some important way as well, when God is understood as the creator. Some have even included logical and mathematical principles as things dependent on God, though it is less obvious how mathematical principles may be considered norms. ${ }^{30}$ The motivation for exploring these possibilities is similar to one of the motivations for the IV - a belief in the importance of the aseity and sovereignty of God, and religious practitioners may site theological doctrines or scriptural sources as motivations supporting the importance of these traits. ${ }^{31}$

\section{Conclusion}

In conclusion, I have argued that one can consistently affirm that the fundamental moral principles are objective, invariable, universal, nonarbitrary and yet are dependent on God. Assume that God is identical with the Good, as the IV asserts, and conjoin this claim with the DWT. These theses are themselves coherent and together show that $\mathrm{O}$ and $\mathrm{G}$ are consistent. Both the IV and DWT may have problematic issues to address as do all philosophical theses, but none is decisive in showing the IV or DWT impossible. They are proposed here are models and although some attempt has been made to increase their plausibility, no attempt has been made to argue for their truth. The IV and DWT are consistent with one another and complement one

29. Such as found in Warrant and Proper Function (New York: Oxford University Press, 1993).

30. Mann, "Modality, Morality, and God," 83-99; Thomas V. Morris and Christopher Menzel, "Absolute Creation," in Anselmian Explorations: Essays in Philosophical Theology (Notre Dame, IN: University of Notre Dame Press, 1987), 161-78; Christopher Menzel, "Theism, Platonism, and the Metaphysics of Mathematics," Faith and Philosophy 4 (1987): 365-82; and Richard Brian Davis, The Metaphysics of Theism and Modality (New York: Peter Lang, 2001).

31. E.g., Isa. 40:13-14. 
another. Though responding to the coherency dilemma by appealing to the idea of simplicity imports several problems, the IV does not fall to the same objections. The IV conjoined with a moral theory such as DWT explains the moral supremacy of God, while allowing for the truth of $\mathrm{O}$ since morality is rooted in the eternal unchanging standard of the Good. ${ }^{32}$ 